The explorer then again descended to the coast, covering thirty miles a day. He met the Kite, with the relief party, on August 4, near the head of McCormick's Bay, having completed his original programme to the very letter. The geographical discoveries made by the expedition include the tracing of the Greenland coasts above the 79th parallel, the termination of the continental ice-cap below Victoria Inlet, and the existence of glaciers on all the northern fiords. Many valuable tidal and meteorological observations were also obtained, as well as a quantity of material for the ethnological study of the northern Eskimo, including specimens of their costumes, tents, and sledges. The expedition brings home, besides a number of photographs of natives and of Arctic scenery, a large collection of the flora and fauna of the high latitudes visited.

THE four Dundee whaling vessels, whose intended voyage to the Antarctic seas has been already referred to in these notes, sailed from Dundee last week. Three of the vessels carry surgeons who have been specially instructed in making meteorological and biological observations. They are fully equipped with appliances for collecting specimens of every kind. The more strictly geographical conditions will be observed by the captains, who have been supplied with additional instruments to enable them to lay down their track with a greater degree of accuracy than would be necessary in ordinary circumstances. Their long Arctic experience fits them for navigating the icehampered waters of the South and for comparing the conditions found there with those of the better-known North Polar zone.

THE railway from Jaffa to Jerusalem is now practically completed, and will be opened for traffic before the end of this month. Recent events in Russia have caused a great increase in the Jewish population of Jerusalem, leading to the extension of the city beyond the walls. The railway will do much to promote the prosperity of Palestine and will probably be largely utilized.

The Gilbert Islands, in the Central Pacific, have been definitely brought under British protection. The group is bisected by the equator, and forms the central link in the long chain of coral and volcanic islands which stretches from the northern to the southern tropic between the meridians of $160^{\circ}$ and $180^{\circ} \mathrm{E}$. The Marshall Islands, which are the most northerly of this chain, are under German control.

THE Proceedings of the Royal Geographical Society for September publishes an interesting account of a journey in Sikkim undertaken by $\mathrm{Mr}$. C. White and Mr. Hoffman in July I89I, with the purpose of exploring and photographing the surroundings of Kanchinjinga. The travellers crossed by the Zeumtso La pass into the Tremu Valley, the magnificent glacier in which was visited for the first time by Europeans. The main glacier-fifteen miles long-is joined by the union of six smaller glaciers, and several others were observed which could not be approached. The Tremu Valley was proved to be only a fortnight's journey from Darjiling, a fact which makes the almost entire ignorance of the existence of glaciers in it very remarkable.

IN the course of his travels into the interior of Iceland (Petermann's Mitteilungen, vol. 38), Th. Thoroddsen discovered an unknown lake in the unexplored region of VatnaJökull. "The greatest part of the western edge of the VatnaJökull is formed by a mighty glacier, whose margin stretches with faint curvature towards the southern horizon. The mountain chains which reach the glacier are powerless to influence its shape. We were surprised by the discovery of a very long lake, stretching from the margin of the glacier close to us towards the south-west as far as the eye could see, and filling up the valley between us and a parallel mountain chain. The narrow lake is of a milk-white colour, formed as it is by glacier ice. I named it Langisjor. The glacier reaches with its steep flank to the north end of the lake, and as it is riddled with clefts it is impossible to ride round on this side. The landscape round the lake is of magnificent beauty, only vegetation is quite absent. The greenish-white lake is surrounded by red and yellow tuff hills, with innumerable fantastic points and summits. On the other side of the chain which terminates the lake in the south stretches an extensive flat plateau, in which glitters a large watercourse, probably the Skapta, and far to the south are seen some great lava streams, dating probably from the 1783 eruption."

NO. I I 94, vOL. 46]

\section{INTERNATIONAL CONGRESS OF PHYSIOLOGISTS.}

THE second International Congress of Physiologists, which took place at Liège on August 29, 30, and 31, was attended by more than roo physiologists, including among others :- Prof. F. Holmgren (Upsala), President of the Congress, Profs. Hensen, Hürthle, Kühne, Rosenthal, Cybulski, Kronecker, Miescher, Fredericq, Héger, Heymans, Arloing, Chauveau, Dastre, Gréhant, Hédon, Langlois, Laulanié, Morat, Wertheimer, Hamburger, Grigorescu, Wedensky, and the following English members : Profs. Foster, Burdon Sanderson, Schäfer, Allen, Gotch, Halliburton, Horsley, Purser, Waymouth Reid, Stirling, Waller, Drs. Adami, Beevor, Paton, Martin, Mott, Pye-Smith, Sherrington, Starling, Shore, Sims Woodhead; Messrs. Bayliss, Burch, and Parsons.

The work of the Congress was carried on in the Institutes of Zoology and Physiology, these institutions being placed at the disposal of the members by the kind courtesy of the two directing professors, whilst in addition the whole arrangements were excellently organized through the energy of the Professor of Physiology, Prof. Léon Fredericq.

The work of each day was so arranged that the mornings only need be devoted to the formal hearing of communications in th: large lecture hall of the Zoological Institute, and the afternoons were thus left entirely free for informal meetings in the Physiological Institute, when demonstrations of special interest were shown in the rooms of the laboratory, thus adding very materially to the interest and utility of the proceedings. The following list of the various communications and demonstration: will at least serve to show the large extent of ground covered by the subject-matter brought forward, and the activity with which physiological research is now being pursued.

Monday, August 29.-Presidents: Prof. Chauveau (Paris), Prof. Burdon Sanderson (Oxford).

\section{A. Communications.}

I. Hermann. -Phonoplrotography.

2. Rosenthal.-Results of observations with improved calorimetric methods.

3. Halliburton.-Nucleo-albumins.

4. Starling. - The fate of peptones in the blood and the lymph.

5. Max Cremer.-Experiments on the effects of feeding animals with certain sugars.

6. Langlois. - The functions of the suprarenal bodies.

7. Morat.-The innervation of the tensor tympani.

8. Hamburger.--The effect of different salts upon the properties of red blood corpuscles.

9. Céline Muro.--Physiological evolution.

\section{B. Demonstrations.}

1. Huirthle.-A new method of registering the sounds of the heart in man by means of a microphone.

2. Wertheimer.- (a) The excretion by the liver of bile introduced into the blood.

(b) Vaso-dilatation effects of strychnia.

3. Laulanié.-The cardiograph (needle method).

4. Wedensky.-Demonstration by the telephone of the electrical changes which accompany the passage of nerve im. pulses, and the influence upon these of electrotonic alterations in nerve excitability.

5. Sherrington.- The cortical representation of the move ments of the hallux and especially of the anus in the Macaque monkey.

6. Langlois. - The variations in the discharge of heat during "la maladie pyocyanique."

Tuesday, August 30.-Presidents: Prof. Kühne (Heidelberg), Prof. HÉger (Brussels).

\section{A. Communications.}

I. Bowditch.-Composite photography.

2. Olivier.-Protoplasmic continuity.

3. Schäfer. - The structure of the insect's wing muscles.

4. Schäfer.-The negative effects of severance of the frontal lobes of the cerebrum.

5. Vitzou, - (a) The visual centres of the dog and monkey.

(b) The effects of total ablation of a cerebral hemisphere. 
6. Wertheimer.-The elimination of pigments by the liver. 7. Loew. - The distinction between the "active" and the " passive" albuminous material of plants.

8. Sherrington.-The varieties of leucocytes.

\section{B. Demonstrations.}

I. Chauveau.-The changes in mammalian endocardiac pressure as recorded by the tambour and air transmission method. (This classical experiment formed the main part of the afternoon's work.)

2. Gréhant.- (a) Absorption of carbonic oxide by living organisms.

3. Gréhant and Martin.-On the physiological effects of opium.

4. Wedensky.-Demonstrations with the telephone upon nerve excitation and upon voluntary muscular contraction in man.

5. Zwaardemaker.-The mechanism of smell.

Wednesday, August 3I.-Presidents: Prof. Wedensky (St. Petersburg), Prof. GrigoresCu (Bucharest).

\section{A. Communications.}

x. Cybulski.- The use of the condensor for the excitation of muscles and of nerves.

2. Hédon. - The effect of removal and of transplantation of the pancreas upon the production of diabetes mellitus.

3. Gotch.-The increased excitability of nerve and of muscle occasioned by low temperature.

4. Burch. - (a) The apparatus for photographing the movements of the capillary electrometer.

(b) The method of analyzing the electrometer curves obtained by the photographic method.

5. Burdon Sanderson. - The electrical changes in muscle as shown by the capillary electrometer.

6. Fredericq. - Autotomy in crabs.

7. Jacobi. - The muscular sense.

8. Bayliss. - The functions of the depressor nerve.

9. Doyon.-Tetanus.

Io. Wedensky. - The impossibility of causing fatigue in motor nerves.

II. Verworn.-The effect of galvanic currents on simple living organisms.

12. Moussu. - The functions of the thyroid body.

13. Slosse.-(a) The functions of the thyroid body;

(b) Autopsy of a case of thyrodectomy in the dog.

14. Kaufman. - The intra-muscular circulation.

15. De Boeck. - The effects of partial ablation of the cerebrum immediately after birth.

\section{B. Demonstrations.}

I. Waller.-The discharge of heat from the muscles of man.

2. Gotch. - The increased excitability of the sciatic nerve of the cat produced by low temperature.

3. Grigorescu.-Action of certain poisons upon the central nervous system.

4. Cybulski.--Method of stimulating muscle and nerve by means of condensor discharges.

5. Mares. - Nerve excitation by means of varying induced currents due to variations in the rapidity of magneto-induction.

6. Wedensky. - The most favourable and the least favourable frequency for effective intermittent excitation of nerve by electrical currents.

7. Paton.-A crystalline globulin obtained from urine.

In addition the following members showed instruments and models :-

I. Lahousse.-Model of the nerve centres.

2. Kosenthal.-Calorimeter with recent improvements.

3. Laulanié.-(a) A universal inscribing manometer.

(b) Apparatus for studying respiratory changes.

4. Morat. $\rightarrow$ Recording apparatus.

5. Cybulski. - The Photohæmotachometer.

6. Miescher and Jacquet.-A recording chronometer.

On Wednesday evening, at the conclusion of the proceedings, the members dined together in the large foyer of the theatre, the President of the Congress, Prof. Holmgren, being in the chair.

NO. I I 94, VOL. 46$]$
As the Congress is held every three years, the next meeting will take place in 1895, and it was decided that in response to the kind and cordial invitation of Prof. Kronecker, the meeting should be held in Berne (Switzerland).

\section{ELECTRO-METALLURG $Y$.}

THIS is not the first time a lecture has been delivered here on electro-metallurgy. I find that so long ago as January, I $84 \mathrm{I}$, there was a lecture on the subject by Mr. Brand.

At that time electro-metallurgy was very new and very small. It consisted solely of electro-plating and electrotype. Electroplating had already begun to be practised as a regular industry, but it was still a question whether the new kind of plating was good, and there were not a few silversmiths who would not offer electro-plate for sale because of its supposed inferiority to plate of the old style. That question has long been definitely settled by the fact that every week more than a ton of silver is deposited in the form of electro-plate.

Electrotype in $184 \mathrm{I}$ was not so far advanced-it had not then been taken hold of by the artisan and manufacturer-it was still in the hands of the amateur.

While the voltaic battery was the cheapest source of electric current, electro-metallurgy was necessarily restricted to artistic metal work, or to those applications where the fine quality of the electrotype cast outweighed the consideration of its cost, or where only a thin film of metal was required for the protection of a baser metal from the action of the air.

Within this limited field, the electro deposition of copper, of gold, of silver, of iron, and of nickel, has been carried on commercially with very great success and advantage for almost the whole period of the existence of the art. But beyond these bounds, set by the limitation of cost, it could not pass.

Now, all this is changed-since engineer and electrician have united their efforts to push to the utmost the practical effect of Faraday's great discovery, of the principle of generating electric currents by motive power. The outcome is the modern dynamo, with its result-cheap electricity. The same cause that has led to electric lighting, and to the electric transmission of power, has also led to a very great development of electro-metallurgic industry, and not only in the old directions but in new. It is no longer a matter of depositing ounces or pounds of metal, but of tons and thousands of tons. And it is no longer with metal deposition merely that electro-metallurgy now deals, but also with the extraction of metals from their ores, and the fusion and welding of metals. Electro-metallurgy has in fact grown so large and many-branching, that it is impossible to treat it in a complete manner in a single hour.

One of the latest developments is electric welding. This, in one of its forms, that invented by Elihu Thompson, has recently been so thoroughly explained and demonstrated by Sir Frederick Bramwell, that it is not necessary for me to do more than mention it as belonging to the subject.

There is also another species of electric welding - that of Dr. Benardos-in which the electric arc is used after the manner of a blow-pipe flame, to obtain the welding of such forms and thicknesses of iron, steel, and other metals, as would be difficult or impossible to weld in any other way; and not only is the electric blow-pipe used for welding, but also for the repair of defects in steel and iron castings, by the fusion of pieces of metal, of the same kind as the casting, into the faulty place, so as to make it completely sound. This new kind of electric welding, as improved by Mr. Howard, is now of sufficient importance to entitle it to the full occupation of an evening. I therefore propose to leave it for detailed description to some other lecturer, and content myself with calling your attention to the interesting collection of specimens on the table, and in the Library (lent by Messrs. Lloyd and Lloyd), showing the results of this process.

Even with this curtailment, the extent of the field is still too great, and I must reduce it further by omitting a considerable section of that portion which relates to the extraction of metals from their ores, and, in this connection, only speak of the extraction of aluminium

But, in the first place, I am going to speak of the deposition of copper, and you will pardon me if I treat it as if you were unacquainted with the subject.

1 Friday evening discourse delivered by Mr. J. Wilson Swan, at the Royal Institution, on May 20. 